Original Research Article

\title{
Physico-chemical properties and antibacterial drug performance of amoxicillin from streets in Bamenda, Cameroon
}

\author{
Gerald N. Teke ${ }^{1 *}$, Christian V. Junior ${ }^{2}$, Stephen L. Tamekou ${ }^{3}$, Penn-Edelqueen W. Nkengla ${ }^{2}$, \\ Jules R. Kuiate ${ }^{3}$
}

${ }^{1}$ Department of Biomedical Sciences, Faculty of Health Sciences, The University of Bamenda, Bambili, Cameroon ${ }^{2}$ Department of Biochemistry, Faculty of Sciences, The University of Bamenda, Bambili, Cameroon ${ }^{3}$ Department of Biochemistry, Faculty of Sciences, University of Dschang, Cameroon

Received: 29 April 2019

Accepted: 30 May 2019

*Correspondence to: Dr. Gerald N. Teke,

Email:ngobob@yahoo.com

Copyright: () the author(s), publisher and licensee Medip Academy. This is an openaccess article distributed under the terms of the Creative Commons Attribution NonCommercial License, which permits unrestricted noncommercial use, distribution, and reproduction in any medium, provided the original work is properly cited.

\begin{abstract}
Background: The advent of microbial drug resistance creates a concern about the quality of anti-infective drugs. The rise in some microbial resistance to therapy has urged us to investigate physico-chemical properties and antibacterial performance of amoxicillin from streets in Bamenda, Cameroon.

Methods: Amoxicillin samples were purchased from street vendors in Bamenda. Cameroon. Visual inspection was done for defects and signs of discoloration, deterioration or other physical disfiguration. Weight uniformity test for each sample of antibiotic tablet was carried out. The time for drug disintegration for each sample of amoxicillin was evaluated. Microbial antibiotic susceptibility tests were done using both the agar disc diffusion and micro well broth dilution methods to check drug performance. Data analysis was done and comparison checked with Student-Newman-Keuls at $\mathrm{p}<0.05$.

Results: The mean weight of amoxicillin drugs ranged from $632.00 \pm 11.5$ to $748.06 \pm 17.9 \mathrm{mg}$. Tablets from Austria had a significant decrease in weight compared to those from Germany and Nigeria. This was similar with the capsules from India and China. Average disintegration varied significantly from as small as 2.2 to 14.4 minutes. All the amoxicillin samples were active against the tested bacteria with mean zones of inhibitions ranging from $8.33 \pm 0.57$ to $39.33 \pm 0.57$ $\mathrm{mm}$. The MICs and MBCs values range from 1 to $64 \mu \mathrm{g} / \mathrm{ml}$. For the same bacterium the growth inhibitory effects of the various drugs were not all similar. Conclusions: Some of the amoxicillin samples studied in this paper showed significant differences in their weights and performances (antibacterial activities). Probably the required amount of API was not respected.
\end{abstract}

Keywords: Antibacterial performance, Amoxicillin, Bamenda-Cameroon, Physico-chemical properties

\section{INTRODUCTION}

The advent of microbial drug resistance creates a concern about the quality of anti-infective drugs; especially in areas of endemic diseases. ${ }^{1}$ The leading group constitutes antibiotics, due to their high demand globally. The highvolume sales of antibiotics attract manufacturers of "counterfeit" drugs making much profit from these medicines and sometimes at the expense of the population health. ${ }^{2}$ It is obvious that use of poor quality drugs can lead to poor treatment outcomes, waste of financial resources due to prolonged illness, increase in the potential of recrudescence, and propagation of drug resistance. ${ }^{3}$ It has been observed that very limited scientific investigations have assessed the prevalence of poor quality antibiotics. ${ }^{4,5}$ Moreover, in the developing world, antibiotics can be 
easily obtained without prescription from pharmacies, drug stores and mobile drug dealers. ${ }^{6}$ Amoxicillin is a $\beta$ lactam antibiotic with a widespread use in the treatment of bacterial infections. In some parts of the world amoxicillin prescription still being the first choice antibiotic. ${ }^{7}$ Although most of the generic drug development are meant to lower public health costs there are still some doubts regarding their qualities and performances compared to branded products. ${ }^{8}$ Hence a substantial amount of locally produced amoxicillin among antibiotics do not complying with the U.S. Pharmacopeia (USP). This has been reported in the Middle East and North Africa. ${ }^{9}$

Some microorganisms have been reported to have some resistance to amoxicillin, for example $S$. aureus, E. coli, and $S$. pneumonie. ${ }^{7,10}$ Antibiotic resistance is a problem so serious that it threatens the achievements of modern medicine. ${ }^{1}$ In the Bamenda community, there are many pharmacies and a great number of drug dealers in streets and local markets. The rise in some microbial resistance to therapy in this area let us to investigate physico-chemical properties and antibacterial performance of amoxicillin from streets in Bamenda, Cameroon.

\section{METHODS}

\section{Determination of physico-chemical properties of the various drug samples}

\section{Antibiotic drugs}

Amoxicillin, commonly used over the counter, antibiotics were purchased from street vendors (five samples each from a different locality) and a reference pharmacy (one sample) in Bamenda, Cameroon.

\section{Visual inspection}

The packages of the various antibiotic drugs were examined for defects and signs of discoloration, deterioration or other physical disfiguration. Dates of manufacture and expiration of each sample were checked and recorded as well as the pharmaceutical form of the drug whether tablet or capsule, powder, ointment or suspension. ${ }^{11}$

\section{Weight uniformity test}

The test for uniformity of weight for each sample of antibiotic tablet was carried out as described by British pharmacopoeia. ${ }^{12}$ The weights of twenty tablets/capsules were individually measured using a Kern ABT 120-40M sensitive electronic balance. The mean standard weight and standard deviation of each tablet/capsule were then determined. ${ }^{13}$

\section{Disintegration test}

For each sample of amoxicillin antibiotic, ten tablets/capsules were individually place in separate beakers containing $5 \mathrm{ml}$ of distilled water all placed in a water bath set at a temperature of $37^{\circ} \mathrm{C}$. The time each tablet took to disintegrate completely was noted and the mean time determined for ten tablets/capsules. ${ }^{13}$

\section{Antibiotic susceptibility test}

\section{Preparation of antibiotic stock solution and test solution}

First a stock solution of the antibiotic was prepared by dissolving a tablet or powder obtained from each capsule of the drug in $4 \mathrm{ml}$ of sterile water; this gave stock solutions varying in concentrations $125 \mathrm{mg} / \mathrm{ml}$ of active ingredient as per drug package. The stock solutions were made in higher concentrations to maintain their qualities when stored at $-20^{\circ} \mathrm{C}$. Once taken out, they were not refrozen or reused. ${ }^{14}$ With a micropipette, $40 \mu \mathrm{l}$ of the different antibiotic drugs with concentrations of 125,000 $\mu \mathrm{g} / \mu \mathrm{l}$ were pipetted and dissolved in $5 \mathrm{ml}$ of sterile distilled water to give a test solution with a concentration of $1,000 \mu \mathrm{g} / \mathrm{ml}$.

\section{Preparation of antibiotic disc}

Using Whatmann No. 1 filter paper, discs of $6 \mathrm{~mm}$ diameter were cut out using a paper puncher. The discs were then separated out in a large size glass Petri dish and sterilized in a $1000^{\mathrm{C}}$ hot air oven for one hour. Then cold and dried paper discs were first dipped in the test solution with a concentration of $1,000 \mu \mathrm{g} / \mathrm{ml}$ and air dried. A $6 \mathrm{~mm}$ disc absorbs approximately $10 \mu \mathrm{l}$ of test solution giving it a drug charge of $10 \mu \mathrm{g}$. ${ }^{15}$

\section{Microorganisms}

Clinical isolates and standard strains of some bacteria were obtained from Pasteur Centre Research Unit YaoundeCameroon. They include five Gram negative (Salmonella typhi ATCC6539, Klebsiella pneumonia ATCC2513883, Escherichia coli ATCC28913, Providencia stuartii) and four Gram positive (Staphylococcus aureus ATCC29213, Staphylococcus aureus ATCC1026, Streptococcus pneumonia, Enterococcus faecalis, ATCC29212) bacteria. These microorganisms were maintained on nutrient agar during the test period.

\section{Preparation of microbial suspension and inoculum}

A flamed sterile wire loop was used to collect a few colonies from 14 hours grown cultures on nutrient agar plates separately and transferred into a corresponding sterile tube containing $5 \mathrm{ml}$ of $0.9 \%$ sterile saline water. The microbial suspensions were the vortexed and their turbidity match with that of $0.5 \mathrm{MacFarland}$ standard. This gave us a microbial suspension with approximately $1.5 \times 10 \neg 8 \mathrm{CFU} / \mathrm{ml}$. A quantity of $466 \mu \mathrm{l}$ of microbial suspension was then pipetted and diluted with $70 \mathrm{ml}$ of $0.9 \%$ saline water giving a final microbial load of $1 \times 106$ $\mathrm{CFU} / \mathrm{ml}$ for agar inoculation. ${ }^{16,17}$ 


\section{Determination of microbial growth inhibition zones}

Agar well diffusion method was used for this assay. Agar plates were prepared using Mueller Hinton Agar (MHA) according to the manufacturer's indications. A volume of $100 \mu \mathrm{l}$ of the inoculum were pipetted and placed on the surface of each agar plate containing and with the aid of a sterile glass spreader rod, the inoculum suspension was evenly spread on the agar surface by streaking. The surface of the seeded plates were allowed to dry for $30 \mathrm{~min}$ before a careful positioning of the prepared antibiotic discs (drug charge of $10 \mu \mathrm{g}$ ) on the solidified agar plates using a sterile forcep. The susceptibility plates were then placed at $37^{\circ} \mathrm{C}$ in incubator for 18 hours. This procedure was repeated for all the samples of amoxicillin antibiotic drugs. After the incubation period, zones of growth inhibition appeared around the antibiotic containing disc for those bacteria that were susceptible to the tested drug. The diameters of zone of inhibition were measured using a ruler held on the back of the inverted Petri plate. Zones were measured to the nearest whole millimeter in a radial manner and their average determined. ${ }^{18,19}$

\section{Determination of minimum inhibitory concentration (MIC)}

Briefly, $100 \mu \mathrm{l}$ of nutrient broth was first introduced into all the wells of the micro-titre plate. Then $100 \mu \mathrm{l}$ of each antibiotic solution with a concentration of $256 \mu \mathrm{g} / \mathrm{ml}$ was further added into the first three wells of each column successively to give a final volume of $200 \mu \mathrm{l}$ in first row of wells. The content of these wells was mixed using a pipette and two-fold serial dilution was performed in a consecutive manner from the first well to the last was and the left over thrown away. This exercise gave antibiotic concentrations of $128,64,32,16,8,4,2$ and $1 \mu \mathrm{l} / \mathrm{ml}$ in each series of wells. Now $100 \mu \mathrm{l}$ of broth containing $2 \times 106 \mathrm{CFU} / \mathrm{ml}$ was then pipetted and added to all the wells of the plate except the first four in the last column which served as a sterility control. The last four wells in that column which were void of antibiotics were inoculated to serve as a positive control. After inoculation, the final antibiotic test concentrations were $64,32,16,8,4,2,1$, and $0.5 \mu \mathrm{g} / \mathrm{ml}$. All the plates were incubated at $37 \mathrm{oC}$ for 18 hours. 20 The MICs of each test sample was detected following addition of $50 \quad \mu l \quad(0.2 \quad \mathrm{mg} / \mathrm{ml}) \quad \mathrm{p}$ iodonitrotetrazolium chloride (INT, Sigma-Aldrich, South Africa) solution into all the wells except for those in column 3, 6, 9 and 11 which are further used for the determination of MBCs. Viable bacteria reduced the clear dye to a pink colour. The MIC corresponded to the lowest well concentration where no colour change was observed, indicating no growth of microorganism. All tests were performed in triplicates. ${ }^{18,19}$

\section{Determination of Minimum Bactericidal Concentrations (MBCs)}

Immediately after reading the results of the MIC for the various drugs on the different bacteria, $150 \mu \mathrm{l}$ of freshly prepared Mueller Hinton broth was pipetted into all the wells of new sterile plates. Then $50 \mu \mathrm{l}$ of broth test mixtures from MIC test that did not receive INT (wells from columns 3, 6, 9 and 11) was then pipetted and added onto the $150 \mu \mathrm{l}$ broth in the new plate in a sequential manner from the first well in the series right down to the well indicating the MIC value. This was procedure was done in duplicate for all the antibiotic samples and bacteria strains. The plates were then incubated at $370 \mathrm{C}$ for 18 hours. The MBCs of each test sample was detected following addition of $50 \mu \mathrm{l}$ INT into all the wells. The $\mathrm{MBC}$ which is the lowest concentration of an antibiotic required to kill a particular bacterium corresponded to the lowest well concentration where no colour change was observed. ${ }^{21}$

\section{Statistical analysis}

Statistical evaluation of the data generated was carried out using Statistical Package for Social Science (SPSS) version 20. Multiple comparisons were done using Student-Newman-Keuls at $\mathrm{p}<0.05$.

\section{RESULTS}

\section{Physico-chemical properties of the various amoxicillin samples}

\section{Visual inspection and categories of samples collected}

All the samples of amoxicillin (amox) collected were perfectly packaged and the visible characteristics such as shape, colour, and any evidence of deterioration or other physical disfiguration normally attributed to poor quality drugs were not observed (Table 1).

From the labels, the approximate shelf-life of all the samples was 3 years except for Amoxicillin1 that was having a shelf-life of 4 years.

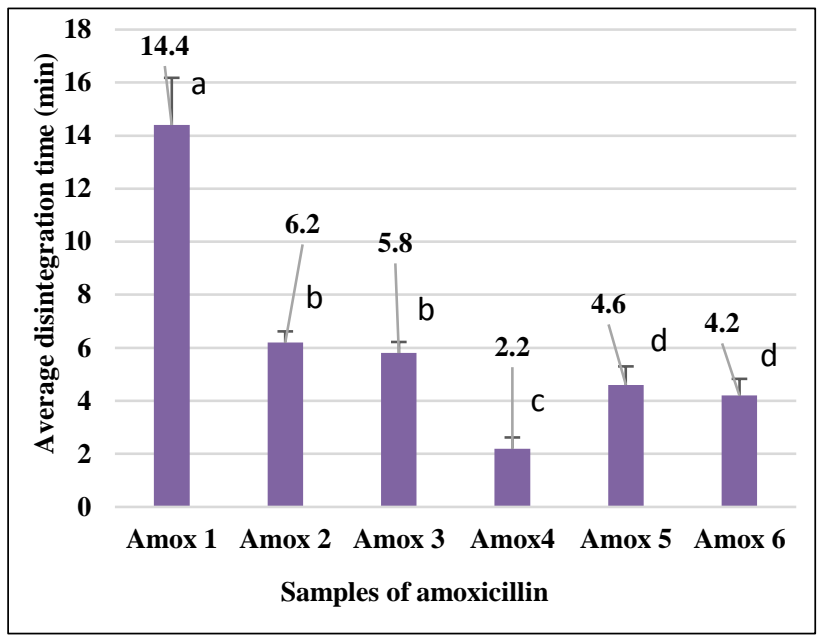

Figure 1: Average disintegration time for the different samples of amoxicillin. 


\section{Average weight of antibiotic drug samples}

The mean weight of amoxicillin drugs in this study ranged from $632.00 \pm 11.5$ to $748.06 \pm 17.9 \mathrm{mg}$ (Table 2). Within these drug samples, the tablets from Austria had a significant decrease in weight compared to those from Germany and Nigeria. This was similar with the capsules from India and China.
Disintegration time of antibiotic drug samples

The average time each samples of amoxicillin drug took to disintegrate completely in water varied significantly from as small as 2.2 minutes in sample 4 (amox 4), to 14.4 minutes (amox 1) as indicated on Figure 1.

Table 1: Visual inspection features and sources of the various antibiotic drugs sampled.

\begin{tabular}{|lllllll|}
\hline Sample & Collection point & $\begin{array}{l}\text { Country } \\
\text { of origin }\end{array}$ & Expiring date & $\begin{array}{l}\text { Shelf-life } \\
\text { (years) }\end{array}$ & $\begin{array}{l}\text { Pharmaceutical } \\
\text { form }\end{array}$ & Colour \\
\hline Amox 1 & Licensed pharmacy & Austria & $07 / 2017-07 / 2021$ & 4 & Tablet & Gray \\
\hline Amox 2 & Local market & India & $02 / 2018-01 / 2021$ & 3 & Capsule & Yellow-red \\
\hline Amox 3 & Local market & China & $02 / 2018-01 / 2021$ & 3 & Capsule & White-orange \\
\hline Amox 4 & Local market & Germany & $04 / 2018-04 / 2021$ & 3 & Tablet & White \\
\hline Amox 5 & Local market & China & $09 / 2017-09 / 2020$ & 3 & Capsule & Yellow-red \\
\hline Amox 6 & Local market & Nigeria & $01 / 2018-01 / 2021$ & 3 & Tablet & White \\
\hline
\end{tabular}

Table 2: Average weights of the various antibiotic drug groups.

\begin{tabular}{|llll|}
\hline Samples (form) & Brand/Country of origin & $\begin{array}{l}\text { Average weight } \pm \text { Standard } \\
\text { Deviation }(\mathbf{m g}) \mathbf{N = 2 0}\end{array}$ & $\begin{array}{l}\text { Relative standard } \\
\text { deviation (\%) }\end{array}$ \\
\hline Amox 1 (Tablet) & Amoxycillin/Austria & $670.27 \pm 2.8^{\mathrm{b}}$ & 0.4 \\
\hline Amox 2 (Capsule) & Healmoxy/India & $684.93 \pm 9.7^{\mathrm{c}}$ & 1.4 \\
\hline Amox 3 (Capsule) & Healmoxy/China & $632.00 \pm 11.5^{\mathrm{a}}$ & 1.8 \\
\hline Amox 4 (Tablet) & Amozem/Germany & $745.44 \pm 8.4^{\mathrm{d}}$ & 1.1 \\
\hline Amox 5 (Capsule) & Amoxicillin/China & $685.58 \pm 7.7^{\mathrm{c}}$ & 1.1 \\
\hline Amox 6 (Tablet) & Amoxicillin/Nigeria & $748.06 \pm 17.9^{\mathrm{d}}$ & 2.4 \\
\hline
\end{tabular}

Table 3: Mean diameters (mm) of inhibition zones of the various samples of amoxicillin against test organisms.

\begin{tabular}{|c|c|c|c|c|c|c|}
\hline Bacteria & $A \operatorname{mox} 1$ & Amoxi 2 & Amox 3 & Amox 4 & $A \operatorname{mox} 5$ & $A \operatorname{mox} 6$ \\
\hline $\begin{array}{l}\text { Staphylococcus aureus } \\
\text { ATCC } 1026\end{array}$ & $23.00 \pm 3.07^{\mathrm{a}}$ & $14.67 \pm 3.02^{b}$ & $23.67 \pm 1.87^{\mathrm{a}}$ & $22.00 \pm 3.08^{\mathrm{a}}$ & $15.48 \pm 0.76^{\mathrm{b}}$ & $12.33 \pm 2.08^{c}$ \\
\hline Streptococcus pneumonae & $35.67 \pm 0.57^{\mathrm{a}}$ & $37.17 \pm 1.67^{\mathrm{a}}$ & $35.67 \pm 1.53^{\mathrm{a}}$ & $35.33 \pm 0.57^{\mathrm{a}}$ & $34.98 \pm 0.65^{\mathrm{a}}$ & $25.67 \pm 0.57^{b}$ \\
\hline $\begin{array}{l}\text { Enterococcus faecalis } \\
\text { ATCC29212 }\end{array}$ & $39.00 \pm 1.00^{\mathrm{a}}$ & $32.67 \pm 0.57^{\mathrm{b}}$ & $33.00 \pm 2.00^{\mathrm{b}}$ & $32.00 \pm 1.00^{\mathrm{b}}$ & $34.52 \pm 0.57^{\mathrm{b}}$ & $33.00 \pm 1.00^{\mathrm{b}}$ \\
\hline $\begin{array}{l}\text { Staphylococcus aureus } \\
\text { ATCC } 29213\end{array}$ & $39.67 \pm 0.57^{\mathrm{a}}$ & $36.33 \pm 0.58^{\mathrm{b}}$ & $32.33 \pm 0.33^{c}$ & $35.67 \pm 0.58^{\mathrm{b}}$ & $32.18 \pm 0.25^{\mathrm{c}}$ & $29.67 \pm 1.53^{\mathrm{d}}$ \\
\hline Salmonella typhiATCC6539 & $21.67 \pm 1.52^{\mathrm{a}}$ & $9.33 \pm 0.57^{d}$ & $17.33 \pm 0.58^{\mathrm{b}}$ & $17.35 \pm 0.57^{\mathrm{b}}$ & $18.53 \pm 1.00^{\mathrm{b}}$ & $12.00 \pm 2.65^{\mathrm{c}}$ \\
\hline $\begin{array}{l}\text { Klebsiellapneumonae } \\
\text { ATCC2513883 }\end{array}$ & $24.67 \pm 3.33^{\mathrm{b}}$ & $17.67 \pm 2.15^{c}$ & $27.68 \pm 3.81^{\mathrm{a}}$ & $20.67 \pm 2.51^{\mathrm{bc}}$ & $20.66 \pm 1.82^{\mathrm{bc}}$ & $19.67 \pm 0.57^{\mathrm{c}}$ \\
\hline $\begin{array}{l}\text { Escherichia coli } \\
\text { ATCC } 28913\end{array}$ & $18.67 \pm 0.58^{a}$ & $10.33 \pm 2.08^{c}$ & $15.33 \pm 1.53^{b}$ & $17.67 \pm 0.58^{\mathrm{a}}$ & $14.85 \pm 0.57^{\mathrm{b}}$ & $11.67 \pm 1.00^{c}$ \\
\hline Providencia stuartii & $39.33 \pm 0.57^{\mathrm{a}}$ & $38.33 \pm 0.57^{\mathrm{ab}}$ & $35.33 \pm 0.57^{\mathrm{ab}}$ & $33.33 \pm 2.51^{\mathrm{b}}$ & $34.32 \pm 0.57^{\mathrm{b}}$ & $26.67 \pm 4.51^{\mathrm{c}}$ \\
\hline
\end{tabular}

\section{Antibacterial activity of amoxicillin samples}

Diameter of bacterial growth inhibition

All the amoxicillin samples were active against the tested bacteria with mean zones of inhibitions ranging from $8.33 \pm 0.57$ to $39.33 \pm 0.57 \mathrm{~mm}$ (Table 3 ). Generally, the mean zones of bacterial growth inhibition for the same bacterium varied significantly for the different amoxicillin samples tested.

\section{MICs/MBCs $(\mu \mathrm{g} / \mathrm{ml})$ of amoxicillin samples}

The MICs and MBCs of the studied amoxicillin samples against bacterial growth (Table 4) showed that values range from 1 to $64 \mu \mathrm{g} / \mathrm{ml}$. For the same bacterium the 
growth inhibitory effects of the various drugs were not all similar.

Table 4: Minimal inhibitory concentration (MBC)/minimum bactericidal concentration (MBC) of test substances $(\mu \mathrm{g} / \mathrm{ml})$.

\begin{tabular}{|lllllll|}
\hline Bacteria & Amox 1 & Amoxi 2 & Amox 3 & Amox 4 & Amox 5 & Amox 6 \\
\hline Staphylococcus aureus ATCC1026 & $4 / 16$ & $8 / 16$ & $32 />64$ & $4 / 16$ & $4 / 16$ & $32 />64$ \\
\hline Streptococcus pneumonae & $8 / 16$ & $8 / 32$ & $16 / 32$ & $8 / 16$ & $8 / 32$ & $16 / 32$ \\
\hline Enterococcus faecalis ATCC29212 & $4 />64$ & $8 />64$ & $8 />64$ & $4 />64$ & $8 />64$ & $8 />64$ \\
\hline Staphylococcus aureus ATCC29213 & $4 / 32$ & $8 / 32$ & $8 / 32$ & $4 / 16$ & $4 / 16$ & $8 / 32$ \\
\hline Salmonella typhiATCC6539 & $32 / 64$ & $>64 />64$ & $32 />64$ & $64 />64$ & $32 / 64$ & $64 />64$ \\
\hline Klebsiella pneumonae ATCC2513883 & $16 / 32$ & $>64 />64$ & $64 />64$ & $64 />64$ & $32 / 64$ & $64 />64$ \\
\hline Escherichia coli ATCC28913 & $32 / 64$ & $>64 />64$ & $64 />64$ & $64 />64$ & $32 / 64$ & $64 />64$ \\
\hline Providencia stuartii & $1 / 16$ & $2 / 16$ & $2 / 16$ & $2 / 16$ & $1 / 16$ & $2 / 16$ \\
\hline
\end{tabular}

\section{DISCUSSION}

From the average weights of twenty tablets or capsules of the different amoxicillin drugs it was observed that tablets from different brands (Amoxycillin/Austria, Amozem/Germany, and Amoxicillin/Nigeria) had significantly different weights. Since the manufacturers were different but having the same rate of active pharmaceutical ingredient (API) $500 \mathrm{mg}$, then excipients could account for these differences.

Surprisingly, the capsules from the same brand (manufacturer) i.e. Healmoxy from both India and China though rated $500 \mathrm{mg}$ presented a great significant difference in their weights. If these drugs are all genuine and produced by the same manufacturer then the discrepancy in their weights should not be significantly wide. This could be from the excipient, API or both. The dose uniformity and active ingredient homogeneity in drugs/capsules relate directly to the necessary approval requirements of the average weight assay. Once a known weight difference is distinguished it is impossible to assure the active ingredient content of all capsules. ${ }^{22,23}$

The drug dissolution assay performed on the studied amoxicillin samples showed that they were readily soluble in water, taking at most $14 \mathrm{~min}$ to dissolve. It is worth mentioning that Amox 1 was bought from a licensed pharmacy while the other samples were obtained from the streets. According to the US Pharmacopoeia the dissolution time for a good drug should be less than or equal to 30 min. ${ }^{24}$ The Brazilian Pharmacopoeia establishes the tolerance limit as not less than $80 \%$ of the declared released amount into the dissolution medium in 90 minutes. ${ }^{25}$ Judging from this dissolution time assay, one could be tempted to say all these drugs are of quality.

Generally, the amoxicillin sample from the pharmacy (amox1) was more active in inhibiting the growth of the studied bacteria. Be it tablet or capsule what is important is the amount of API (amoxicillin). All the drugs as per their manufacturers were rated $500 \mathrm{mg}$. It was expected that for the same bacterium their activity against bacterial growth should be similar. However, in many cases it was not so. One could think of a reduction in the quantity of PI in some Amoxicillin samples (brands) could account for a decrease in drug performance (in inhibiting bacterial growth. If poor quality medicines contain less than the intended API, pathogens can become exposed to drug concentrations in the 'mutation selection window'-high enough to exert a selection pressure but too low to kill all of the pathogens. ${ }^{26}$ Insufficient amount of API may have as consequence the potential to promote antimicrobial resistance (AMR) and treatment failure, now recognized as a major threat to global public health. ${ }^{27,28}$ Studies have shown that substandard antibiotics as well as other essential medicines could be due to either poor manufacturing practices or poor storage and transport conditions or both. ${ }^{27}$ Although it was not determined how long the imported samples have been stored under tropical climatic conditions, most of the street medicines under poor conservation methods could have a decrease in performance.

\section{CONCLUSION}

The Amoxicillin samples studied in this paper showed significant differences in their weights and performances (antibacterial activities). Samples that showed weak antibacterial activity certainly did not contain the required amount of API. The sources and uses of anti-infective agents should be strictly monitored by appropriate personnel.

\section{ACKNOWLEDGEMENTS}

Authors would like to the post graduate students who worked in the Laboratory of Microbiology and Antimicrobial Substances, at the time this study was done, for their technical assistance.

\section{Funding: No funding sources}


Conflict of interest: None declared

Ethical approval: The study was approved by the Institutional Ethics Committee

\section{REFERENCES}

1. Haque M, Nor IR, Zainal Z, Salwani I. Antibiotic prescribing and resistance: knowledge level of medical students of clinical years of University Sultan Zainal Abidin, Malaysia. Ther Clin Risk Manag. 2016;12:413-26.

2. Ifeyinwa F, Mirza L, Naiela M, Albert VW, Harparkash K. Quality of the Antibiotics- amoxicillin and co-trimoxazole from Ghana, Nigeria, and the United Kingdom. Am. J. Trop. Med. Hyg. 2015;92(6):87-94.

3. Newton PN, Green MD, Fernandez FM. Impact of poor quality medicines in the 'developing' world. Trends Pharmacol Sci. 2010;31:99-101.

4. Seear M, Gandhi D, Carr R, Dayal A, Raghavan D, Sharma N. The need for better data about counterfeit drugs in developing countries: a proposed standard research methodology tested in Chennai, India. J Clin Pharm Ther. 2011;36:488-95.

5. Kelesidis T, Kelesidis I, Rafailidis PI, Falagas ME. Counterfeit or substandard antimicrobial drugs: a review of the scientific evidence. J Antimicrob Chemother. 2007;60:214-36.

6. Al Shami A, Izham M, Abdo Rabbo A. Evaluation of the quality of prescriptions with antibiotics in the government hospitals of Yemen. J Clin Diagn Res. 2011;5:808-12.

7. Adnyana IK, Murtini S, Roni A, Wardani I. Evaluation of antibacterial activity and determination amoxicillin concentration on generic and branded products. Inte J Phar Pharmace Sci. 2013;5(3):353-57.

8. Vasco R, Ricardo G, and Hélder V. Anti-competitive impact of pseudo-generics. J Ind Compet Trade. 2014;14(1):83-98.

9. Kyriacos S, Mroueh M, Chahine RP, Khouzam O. Quality of amoxicillin formulations in some Arab countries. J Clin Pharm Ther. 2008;33:375-79.

10. Groppo FC, Castro FM, Pacheco AB, Motta RH, Filho TR, Ramacciato JC, et al. Antimicrobial resistance of staphylococcus aureus and oral streptococci strains from high risk endocarditis patients. PubMed. 2005;53(6):410-3.

11. Habyalimana V, Kindenge JM, Kalenda NT, Dispas A, Yemoa AL, Pierre YS, et al. Analytical tools and strategic approach to detect poor quality medicines, identify unknown components, and timely alerts for appropriate measures: case study of antimalarial medicines. Ame J Ana Chemist. 2015;6:977-94.

12. Okorie O, Azaka JE, Amadi CM. Pharmaceutical quality assurance of omeprazole capsule brands commonly used in health institutions in southern nigeria. Ame J Pharma Pharmacol. 2016;3(4):33-9.

13. Soyinka JO, Faleye FJ, Adetogun GE. Quality evaluation of some brands of vitamin $\mathrm{C}$ preparations. Nige J Phar Res. 2008;7(1):12-7.
14. Chen X. Determination of the minimum inhibitory concentrations (MICs) and the minimum bactericidal concentrations (MBCs) for a novel antibiotic. Afr J Micro Res. 2011;5(5):572-5.

15. Vineetha N, Vignesh RA, Sridhar D. Preparation, standardization of antibiotic disc and study of resistance pattern for first-line antibiotics in isolates from clinical samples. international journal of applied research. 2015;1(11):624-31.

16. Cheesbrough M. District Laboratory Practice in Tropical Countries. $2^{\text {nd }}$ ed. New York, Cambridge University Press; 2006:178-194.

17. Gerald NT, Betie EN. Antibacterial activity of three cameroonian honey types against some pathogenic species. Int J Biol Chem Sci. 2016;10(6):2477-84.

18. Teke GN, Kemadjou NE, Kuiate JR. Chemical composition, antimicrobial properties and toxicity evaluation of the essential oil of cupressus lusitanica mill. leaves from Cameroon. BMC Compl Alter Med. 2013;13(1):130.

19. Chattopadhyay D, Maiti K, Kundu AP, Chakraborty MS, Bhadra R, Mandal SC, et al. Antimicrobial activity of Astonia macrophylla: a folklore of Bay Islands. J Ethnopharmacol. 2001;77(1):49-55.

20. Hafiz MA, Omair AM, Muhammad BA. Comparative in vitro antibacterial analysis of different brands of cefixime against clinical isolates of Staphylococcus aureus and Escherichia coli. J App Phar Sci. 2012;2(1):109-13.

21. Gerald NT, Ngolle GE, Akah RT. In vitro antimicrobial activity of some commercial toothpastes. Int J Curr Microbiol App Sci. 2017;6(1):433-46.

22. Marques Marinho FD, Vianna Soares CD, Carmo VAS, Campos LMM. Quality evaluation of pantoprazole gastro-resistant compounded capsules. Lat Am J Pharm. 2009;28(6):899-906.

23. Scheshowitsch K, Pereira A, Cruz A, Silva MAS, Stulzer HK. Quality evaluation and dissolution profile of piroxicam manipulated capsules. Lat Am J Pharm. 2007;26(5):645-51.

24. Vogelpoel H, Welink J, Amidon GL, Junginger HE, Midha KK, Moller H, et al. Biowaiver monographs for immediate release solid oral dosage forms based on biopharmaceutics classification system (BCS) literature data: verapamil hydrochloride, propranolol hydrochloride, and atenolol. J Pharm Sci. 2004;93:1945-56.

25. Fúlvio GC, Blanca EOM, Paulo CPR. Physicochemical quality evaluation of amoxicillin capsules produced in compounding pharmacies at Diadema, São Paulo, Brazil. J App Pharm Sci. 2015;5(12):029-34.

26. Abdul Aziz MH, Lipman J, Mouton JW, Hope WW, Roberts JA. Applying pharmacokinetic/pharmacodynamic principles in critically ill patients: optimizing efficacy and reducing resistance development. Seminars in Respiratory and Critical Care Medicine. 2015;36(1):136-53. 
27. William LH, Cormac D, Mycroft HE, Gabriel L. Public health interventions to protect against falsified medicines: a systematic review of internation al, national and local policies. Health Policy and Planning. 2016;31(10):1448-66.

28. Safo OD, Egbo HA, Nettey H, Konadu DY, Mensah AI. Evaluation of the quality of some antibiotics distributed in Accra and Lagos. Int J Pharm Sci Res. 2016;7(5):1991-2000.

Cite this article as: Teke GN, Junior CV, Tamekou SL, Nkengla EWP, Kuiate JR. Physico-chemical properties and antibacterial drug performance of amoxicillin from streets in Bamenda, Cameroon. Int J Basic Clin Pharmacol 2019;8:1615-21. 